\title{
SUMBANGAN PERUBAHAN TEKNOLOGI TERHADAP PERTUMBUHAN OUTPUT INDUSTRI SKEL KECIL DAN SEDERHANA DI MALAYSIA
}

\author{
RAHMAH ISMAIL \\ Fakulti Ekonomi dan Perniagaan \\ Universiti Kebangsaan Malaysia \\ IDRIS JAJRI \\ Fakulti Ekonomi dan Pentadbiran \\ Universiti Malaya
}

\begin{abstract}
ABSTRAK
Industri Skel Kecil dan Sederhana (IKS) memainkan peranan yang amat penting terhadap pertumbuhan ekonomi Malaysia. Bilangan pertumbuhannya yang banyak merangkumi hampir 90\% daripada jumlah pertubuhan sektor pembuatan di Malaysia. Hal ini menjadikan industri ini mempunyai kemampuan yang tinggi dalam menyediakan peluang pekerjaan kepada rakyat. Namun sumbangannya dari segi output tidak setimpal dengan bilangan pertubuhannya dan jauh lebih rendah daripada sumbangan Industri Skel Besar (ISB) yang banyak didominasikan oleh pelabur asing. Jumlah output atau nilai ditambah IKS hanya merangkumi sekitar 30\% daripada keseluruhan ouput pembuatan. Keadaan ini ada kaitannya dengan rendahnya kecekapan IKS dalam mengendalikan aktiviti pengeluarannya dan teknologi yang digunakan jauh terkebelakang daripada yang berlaku dalam ISB. Kedua-dua komponen ini menyumbang kepada rendahnya Pertumbuhan Produktiviti Faktor Keseluruhan (TFPG) IKS. Artikel ini akan menganalisis perubahan kecekapan teknikal, perubahan teknologi dan TFPG dalam IKS. Seterusnya artikel ini melihat sejauh mana perubahan teknologi mempengaruhi pertumbuhan output IKS. Bagi mencapai objektif ini data IKS daripada Penyiasatan Industri Pembuatan, Jabatan Perangkaan Malaysia bagi tempoh 1985-2003 digunakan. IKS didefinisikan sebagai industri dengan bilangan pekerja sepenuh masa kurang daripada 200 orang. Data ini merangkumi 10 sub industri IKS pada tahap pengkelasan Industri Piawaian Malaysia (MSIC) 3 digit. Analisis kertas ini bermula dengan melihat perubahan kecekapan teknikal, perubahan teknologi dan TFPG yang berlaku dalam IKS dengan menggunakan kaedah Data Envelopment Analysis (DEA). Analisis seterusnya ialah menggunakan perubahan teknologi sebagai salah satu pemboleh ubah dalam model pertumbuhan output IKS bersama-sama dengan faktor modal dan buruh untuk melihat sejauh mana perubahan teknologi mempengaruhi pertumbuhan output. Analisis peringkat kedua ini menggunakan kaedah kuasa dua terkecil (OLS).
\end{abstract}




\begin{abstract}
Purpose - The article has two main objectives. Firstly, it analyses technical efficiency, technological change, and total factor productivity (TFP) growth in small and medium industries (SMEs) in Malaysia. Secondly, it examines to what extent technological change influences SMEs output growth.
\end{abstract}

Design/Methodology/Approach - The analysis was based on the Manufacturing Industrial Survey data of 1985-2003 collected by the Department of Statistics Malaysia. SMEs are defined as an industry with less than 200 full-time workers. The study covers 10 SMEs sub-industries at 3 digits of the Manufacturing Standard Industrial Classification (MSIC). In achieving the first objective, the study used Data Envelopment Analysis (DEA). The value of -technological change derived from DEA was then used as the dependent variable in the production function to achieve the second objective.

Findings - The study showed that TFP growth for the overall SMEs is negative due to negative change of both technical change and technological change. -However, analysis at the sub-industry level showed positive TFP growth for food and beverages, textiles, and plastic products, which was due to positive growth of their technical change. Technological change has positive impact on six SMEs sub-industries, i:e. food and beverages, textiles, wood-based products, plastic products, electrical electronics, and transport equipments.

Originality/Value - This article introduces a new measurement for technological change from a DEA approach to be incorporated in the production function.

Keywords - Technical change, technological change, total factor productivity, "output growth, small and medium industries.

Paper type - Research Paper.

\title{
PENGENALAN
}

Strategi pertumbuhan ekonomi Malaysia telah beralih daripada dipacu input (input-driven) kepada dipacu produktiviti (productivity-driven) dan dipacu pengetahuan (knowledge-driven). Dalam era ini pengetahuan dianggap sebagai penyumbang penting kepada pertumbuhan ekonomi. Setelah sekian lama, strategi pertumbuhan berasaskan input diberi penekanan, kerajaan menyedari bahawa strategi ini tidak mampu 
meningkatkan daya saing ekonomi kerana peningkatan input walaupun disusuli dengan peningkatan output akan melibatkan peningkatan dalam kos pengeluaran. Walhal strategi baru yang menekankan produktiviti mampu menjimatkan kos pengeluaran untuk mencapai output dan pertumbuhan yang lebih tinggi. Dalam hal ini, sumbangan Pertumbuhan Produktiviti Faktor Keseluruhan (TFPG) amat ditekankan kerana ia melambangkan peningkatan dalam kualiti bagi keseluruhan input.

Sejarah pertumbuhan ekonomi Malaysia telah menyaksikan rendahnya sumbangan TFPG terhadap pertumbuhan ekonominya. Contohnya, dalam tempoh Rancangan Malaysia Ketujuh (RMK-7), peratus sumbangan TFPG kepada pertumbuhan ekonomi Malaysia adalah 24.0\% berbanding $45.2 \%$ sumbangan input modal dan 30.8\% sumbangan input buruh. Dalam tempoh Rancangan Malaysia Kelapan (RMK-8) peratus sumbangan TFPG meningkat kepada $29.0 \%$ tetapi masih lebih rendah daripada sumbangan input modal dan buruh yang masing-masing menyumbang sebanyak 37.8\% dan 33.2\%. Sasaran Rancangan Malaysia Kesembilan (RMK-9) adalah meningkatkan sumbangan TFPG kepada $35.8 \%$ dan menurunkan sumbangan input modal dan buruh masingmaisng kepada 34.3\% dan 29.9\% (Malaysia 2006). Dalam hal ini industri skel kecil dan sederhana (IKS) tidak terkecuali. Kebanyakan kajian telah menunjukkan pertumbuhan sektor ini lebih didorong oleh pertumbuhan input (lihat umpamanya Rahmah \& Nyet 2002; Rahmah 2007).

Peranan perubahan teknologi kepada pertumbuhan output memang telah lama disedari. Cuma metodologi pengukurannya mengalami evolusi daripada melihat teknologi sebagai faktor baki seperti di zaman teori pertumbuhan ekonomi Solow (1956) atau lebih dikenal sebagai teori pertumbuhan eksogenos kepada mengukur faktor teknologi secara langsung dan menggunakannya sebagai salah satu input dalam fungsi pengeluaran bagi penganggaran model pertumbuhan endogenos. Pendekatan model yang lebih terkini mengakui pentingnya peranan kualiti input sama ada buruh atau modal dalam memberi sumbangan kepada pertumbuhan output negara atau sektor.

Artikel ini bertujuan menganalisis TFPG dalam IKS di Malaysia dan impak perubahan teknologi yang merupakan salah satu komponen TFPG ke atas pertumbuhan output sub IKS yang dikaji. Analisis kertas ini adalah berdasarkan data Penyiasatan Industri Pembuatan, 1985-2003 yang dikutip oleh Jabatan Perangkaan Malaysia. Penggunaan data ini adalah pada tahap Pengelasan Industri Piawaian Malaysia (MSIC) 3 digit. 
Kajian ini mengklasifikasikan 10 sub industri dalam IKS, iaitu makanan dan minuman, tekstil, keluaran kayu, keluaran plastik, keluaran getah, keluaran kimia, keluaran logam, galian bukan logam, elektrik dan elektronik dan kelengkapan pengangkutan. IKS didefinisikan sebagai industri yang mempunyai pekerja sepenuh masa tidak melebihi 200 orang.

Penulisan artikel ini diorganisasikan dalam enam bahagian. Bahagian kedua membincangkan perkembangan dan sumbangan IKS di Malaysia. Ia diikuti dengan kerangka teori dan kajian lepas pada bahagian ketiga dan disusuli dengan spesifikasi model dan data pada bahagian empat. Bahagian kelima membincangkan hasil kajian dan akhir sekali bahagian enam adalah rumusan dan implikasi dasar.

\section{Perkembangan dan Sumbangan IKS di Malaysia}

Berdasarkan kepada Tinjauan Industri Pembuatan yang telah dijalankan oleh Jabatan Perangkaan Malaysia, pada tahun 1985, IKS merangkumi 92.1\% daripada jumlah pertubuhan sektor pembuatan. Namun demikian, peratusnya telah menurun kepada $87.8 \%$ pada tahun $1989,84.5 \%$ pada tahun 1994 dan 82.7\% pada tahun 1999 kesan daripada pengembangan firma ke arah bersaiz besar. Sumbangan IKS terhadap nilai ditambah jauh lebih rendah. Contohnya, pada tahun 1985 sumbangan IKS terhadap nilai ditambah hanya $36.8 \%$, menurun kepada $31.2 \%$ pada tahun 1989 , $26.5 \%$ pada tahun $1994,25.0 \%$ pada tahun $1999,20.5 \%$ pada tahun 2001 dan meningkat kepada $26.6 \%$ pada tahun 2003. Ini menggambarkan nilai ditambah purata setiap firma adalah rendah kesan daripada rendahnya skel pengeluaran mereka.

Analisis dari segi guna tenaga pula menunjukkan pada tahun 1985 -sumbangan IKS agak tinggi, iaitu hampir menyamai ISB. Namun demikian, peratusnya telah menurun daripada $38.0 \%$ pada tahun 1989 kepada 31.5\% dan 31.1\% masing-masing pada tahun 1994 dan 1999 kesan daripada penguncupan peratus bilangan pertubuhan mereka. Walaupun berlaku peningkatan dalam peratus bilangan pertubuhan pada tahun 2001 dan 2003, peratus guna tenaga terus mengalami penurunan. Pada tahun 1985, IKS menyumbang lebih kurang satu pertiga daripada nilai harta tetap sektor pembuatan. Sumbangannya telah menurun kepada lebih kurang satu per empat pada tahun-tahun 1989, 1994 dan 1999. Malah sumbangannya pada tahun 2001 terus menguncup dan meningkat sedikit pada tahun 2003.

Jadual 1 dan Rajah 1 memaparkan beberapa indikator penting IKS dan membandingkannya dengan ISB. Daripada segi nisbah modal-buruh, 
didapati ia jauh lebih rendah dalam IKS dibandingkan dengan ISB sepanjang tempoh kajian, iaitu antara 1985 hingga 2003. Namun demikian, ia mengalami peningkatan yang begitu memberangsangkan bagi IKS daripada hanya RM28.55 ribu pada tahun 1985 kepada RM102.45 ribu pada tahun 2003. Ini menggambarkan berlaku peningkatan penggunaan modal dalam IKS dan sekali gus menggambarkan peningkatan dalam penggunaan teknologi dan intensiti modal.

Nilai ditambah bagi setiap buruh menunujukkan kecekapan dalam penggunaan buruh atau dikenal juga sebagai produktiviti buruh. Didapati sepanjang tempoh antara tahun 1985 hingga 2003, produktiviti buruh ISB adalah lebih tinggi daripada IKS. Walau bagaimanapun peratus perbezaannya telah menurun dari tahun 1985 ke tahun 2003, daripada $68.1 \%$ kepada $35.3 \%$. Ini menunjukkan bahawa berlaku peningkatan yang agak baik dalam produktiviti buruh IKS, walaupun pada kedudukan yang lebih rendah daripada ISB. Keadaan ini adalah disumbangkan oleh peningkatan pencapaian pendidikan dan latihan dalam kalangan pekerja dengan meningkatnya peratus enrolmen peringkat tinggi dan peratus pekerja yang menghadiri latihan.

Satu perkara yang agak menarik ialah produktiviti modal IKS didapati lebih tinggi daripada produktiviti modal ISB di sepanjang tempoh tahun yang diliputi. Ini menunjukkan kecekapan modal IKS adalah lebih tinggi, walaupun berlaku peningkatan yang agak kecil antara tahun 1985 hingga 2003. Keadaan ini boleh menggambarkan beberapa perkara. Pertama, aliran modal yang begitu pesat ke dalam ISB membawa kepada kecekapan modal yang rendah kesan daripada peningkatan kos modal yang tidak setimpal dengan peningkatan nilai ditambah. Kedua, pengaliran modal selalunya disertai dengan pemindahan teknologi dan ini berlaku dengan lebih pesat dalam ISB dibandingkan dengan IKS. Kurangnya kemampuan mengadaptasi teknologi baru menyebabkan penggunaan teknologi yang kurang cekap dan ini membawa kepada kecekapan modal yang rendah dalam ISB. Ketiga, tahap kemahiran buruh dalam ISB yang mungkin tidak mencukupi atau kurang sesuai dengan teknologi juga boleh membawa kepada produktiviti modal yang rendah. Keempat, penyesuaian kepada teknologi baru memakan masa yang agak lama. Dalam tempoh ini kecekapan penggunaan modal menjadi rendah. Keadaan ini juga boleh dikaitkan dengan penggunaan modal yang rendah di kalangan IKS kerana kebanyakan operasi pengeluarannya lebih berintensifkan buruh.

Nilai ditambah per jumlah upah yang mengukur daya saing industri dalam menggunakan buruh, didapati lebih tinggi dalam ISB dibandingkan dengan IKS kecuali pada tahun 2003. Nilai ini yang agak 
stabil antara tahun 1989-2001 bagi IKS yang menggambarkan keupayaan IKS mengekalkan daya saing buruhnya. Malah pada tahun 2003 berlaku peningkatan yang agak tinggi bagi nilai ditambah per jumlah upah dalam IKS. Sebaliknya nilai ditambah per upah bagi ISB mengalami turun naik sepanjang tempoh 1985-2003.

\section{Jadual 1}

\section{Perbandingan Beberapa Indikator Penting dalam IKS dan ISB}

\begin{tabular}{ccccccccc}
\hline & $\begin{array}{c}\text { Nisbah Modal- } \\
\text { Buruh (RM'000) }\end{array}$ & \multicolumn{2}{c}{$\begin{array}{c}\text { Nilai di } \\
\text { Tambah/ Buruh } \\
\text { (RM'000) }\end{array}$} & $\begin{array}{c}\text { Nilai di Tambah/ } \\
\text { Modal } \\
\text { (RM) }\end{array}$ & $\begin{array}{c}\text { Nilai di Tambah/ } \\
\text { Jumlah Upah } \\
(\text { RM })\end{array}$ \\
\cline { 2 - 9 } & IKS & ISB & IKS & ISB & IKS & ISB & IKS & ISB \\
\hline 1985 & 28.55 & 60.89 & 18.92 & 31.81 & 0.66 & 0.52 & 2.85 & 3.72 \\
1989 & 29.57 & 46.15 & 24.17 & 32.77 & 0.82 & 0.71 & 3.34 & 4.14 \\
1994 & 49.46 & 73.50 & 33.88 & 43.43 & 0.68 & 0.59 & 3.26 & 3.80 \\
1999 & 80.35 & 117.47 & 51.98 & 70.34 & 0.65 & 0.60 & 3.77 & 4.21 \\
2001 & 76.16 & 131.44 & 46.42 & 77.37 & 0.61 & 0.59 & 3.15 & 4.11 \\
2003 & 102.45 & 103.24 & 68.75 & 69.65 & 0.67 & 0.67 & 4.17 & 3.86 \\
\hline
\end{tabular}

Sumber. Dihitung dari Penyiasatan Industri Pembuatan, Jabatan Perangkaan Malaysia, pelbagai Tahun

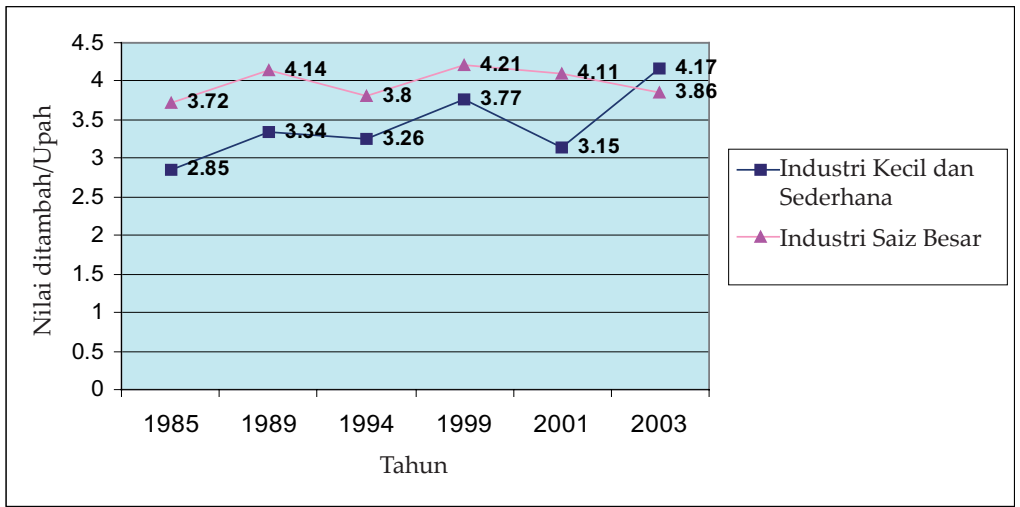

Rajah 1. Perbandingan tingkat daya saing industri, 1985-2003.

Kemampuan ISB menyumbangkan peratus yang besar kepada output atau nilai ditambah boleh dihubungkan dengan tingkat produktiviti mereka yang tinggi, pengurusan yang baik dan skel operasi yang besar yang menyebabkan ISB mampu menikmati faedah ekonomi ikut bidangan. Ini selanjutnya merendahkan kos purata pengeluaran dan meningkatkan kecekapan pengeluaran. Teknologi yang digunakan 
dalam ISB selalunya lebih tinggi dan terkini dibandingkan dengan IKS. ISB juga lebih berintensifkan modal. Pada tahun 2003 misalnya nisbah modal-buruh (K/L) dan produktiviti buruh (V/L) bagi kebanyakan sub industri dalam ISB jauh lebih tinggi daripada IKS seperti ditunjukkan dalam Jadual 2 di bawah.

Jadual 2

Nisbah Modal-Buruh dan Produktiviti Buruh Mengikut Saiz Industri, 2003 (RM'000)

\begin{tabular}{lrrrr}
\hline \multirow{2}{*}{ Jenis Industri } & \multicolumn{2}{c}{ ISB } & \multicolumn{2}{c}{ IKS } \\
\cline { 2 - 5 } \multicolumn{1}{c}{ K/L } & VA/L & \multicolumn{1}{c}{ K/L } & VA/L \\
\hline Makanan (151-154) & 112.26 & 93.03 & 77.22 & 62.60 \\
Minuman dan tembakau (155-160) & 353.73 & 174.48 & 23.94 & 19.39 \\
Tekstil dan pakaian (171-192) & 13.05 & 12.10 & 26.36 & 23.69 \\
Berasaskan kayu (201, 202,361) & 71.32 & 96.35 & 56.71 & 30.03 \\
Keluaran plastik (252) & 66.36 & 48.07 & 96.67 & 71.94 \\
Keluaran getah (251) & 63.41 & 45.57 & 67.38 & 48.37 \\
Kimia (241- 243) & $1,070.74$ & 344.05 & 233.76 & 153.01 \\
Keluaran logam (272) & 204.32 & 95.97 & 75.76 & 57.33 \\
Galian bukan logam (269) & 280.62 & 102.49 & 120.34 & 74.53 \\
Elektrik dan elektronik (291, 323) & 84.70 & 85.51 & 28.58 & 28.23 \\
Kelengkapan pengangkutan (342-359) & 130.22 & 116.45 & 73.41 & 55.02 \\
\hline
\end{tabular}

Nota. Angka dalam kurungan adalah MSIC 3 digit bagi tahun 1981-1999 dan 2000-2003.

Sumber. Dihitung dari data Penyiasatan Industri Pembuatan, 2003. Jabatan Perangkaan Malaysia.

Nisbah modal-buruh adalahlebih tinggi dalam ISB dibandingkan dengan IKS kecuali dalam industri tekstil dan pakaian; berasaskan plastik dan keluaran getah. Dalam ketiga-tiga jenis industri ini, produktiviti buruh juga lebih tinggi dalam IKS. Ini menunjukkan dalam ketiga-tiga jenis industri ini penggunaan buruh adalah lebih efisien bagi industri bersaiz lebih kecil. Keadaan ini mungkin disebabkan oleh kombinasi modalburuh yang lebih sesuai atau pengurusan buruh lebih baik kerana bilangannya yang lebih kecil.

Sektor ISB merupakan sumber pemasaran bagi produk IKS. Dengan kapasiti pengeluarannya yang besar, pasaran yang dapat disediakan adalah luas dan menjadi punca menggalakkan rantaian industri. Dalam Pelan Induk Perindustrian Kedua telah disarankan agar rantaian industri diperkukuhkan bagi pembangunan perindustrian yang lebih mantap (MITI, 1996). Bagi merealisasikan hasrat ini penekanan kerajaan adalah 
menggalakkan ISB supaya menjalin hubungan dengan IKS kerana ISB lebih menguasai pasaran. Mereka perlu digalakkan menggunakan input keluaran tempatan untuk membangunkan industri sokongan (IKS) di samping mengurangkan import yang selanjutnya menjimatkan tukaran wang asing.

\section{KERANGKA TEORI DAN KAJIAN LEPAS}

\section{Kerangka DEA}

Data Envelopment Analysis (DEA) adalah merupakan model pemprogramam linear untuk mengukur kecekapan dan produktiviti. Ia membolehkan kita mengukur perubahan dalam produktiviti keseluruhan dengan menggunakan data panel dan memecahkannya kepada dua bahagian, iaitu perubahan kecekapan teknikal dan perubahan teknologi. TFPG mengukur sejauh mana produktiviti meningkat atau menurun setiap tahun. TFPG meningkat apabila berlakunya pengadaptasian teknologi baru yang dikenal sebagai perubahan teknologi. Begitu juga TFPG boleh meningkatkan kesan daripada teknologi sedia ada tetapi menggunakan input dengan lebih berkesan, maka output boleh ditingkatkan dengan menggunakan jumlah input yang sama, atau dikenal sebagai perubahan kecekapan teknikal. Oleh yang demikian TFPG adalah terdiri daripada perubahan kecekapan teknikal (TEC) dan perubahan teknologi (TC) atau,

$$
\mathrm{TFPG}=\mathrm{TEC} \times \mathrm{TC}
$$

Perubahan teknologi adalah merupakan pembangunan produk baru atau teknologi baru yang membolehkan pembaikan kaedah pengelu"aran dan akhirnya meningkatkan output mencapai frontier. Secara lebih spesifik, perubahan teknologi mengandungi proses pengeluaran baru, yang dikenal sebagai inovasi proses, dan penemuan produk baru, yang dikenal sebagai inovasi produk. Dengan adanya inovasi proses, firma menemui kaedah baru dalam menghasilkan output dan output akan bertambah dengan kadar yang lebih cepat daripada input. Keadaan ini akhirnya membawa kepada penurunan kos pengeluaran. Sementara perubahan kecekapan teknikal membolehkan firma menggunakan modal, buruh dan lain-lain input untuk menghasilkan output yang lebih tinggi. Contohnya, peningkatan dalam kemahiran melalui pembelajaran dengan amalan (learning-by-doing). Apabila pengeluaran mempunyai pengalaman yang lebih tinggi dalam menghasilkan output tertentu, mereka akan menjadi lebih efisien. 


\section{Perkembangan Model Pertumbuhan}

Model pertumbuhan ekonomi Solow (1957) memfokuskan kepada peranan input fizikal, iaitu modal dan buruh kepada pertumbuhan ekonomi, manakala faktor teknologi dan kualiti input dianggap sebagai eksogenos. Dalam model ini pertumbuhan yang seimbang dicapai apabila output dan modal fizikal bertumbuh pada kadar yang sama dengan pertumbuhan penduduk. Keadaan keseimbangan ini dirujuk sebagai Golden Age. Dalam pendekatan ini sumbangan faktor lain seperti teknologi diukur melalui residual. Walau bagaimanapun keputusan kajian-kajian lepas, menunjukkan bahawa modal fizikal dan kuantiti buruh tidak dapat menjelaskan sepenuhnya pertumbuhan output (Schultz 1961; Denison 1974). Kebanyakan kajian mendapati kadar pertumbuhan output melebihi kadar pertumbuhan input, dan lebihan ini terkandung dalam residual. Terdapat pelbagai komponen didalam residual dan penginterpretasiannya adalah mengikut kepentingan masing-masing pengkaji. Teori modal manusia mempercayai bahawa faktor utama dalam residual adalah modal manusia. (lihat umpamanya Lucas 1988; Romer 1989). Pemahaman lain mempercayai bahawa perubahan teknologi adalah kandungan utama residual. Oleh itu, ahli ekonomi yang lebih terkemudian mengembangkan teori pertumbuhan endogenos yang mengambil kira kualiti input seperti buruh dan perubahan teknologi sebagai input langsung dalam fungsi pengeluaran.

Model pertumbuhan endogenos sangat menekankan kepentingan pengetahuan untuk mengelakkan daripada pulangan berkurangan ikut bidangan dan ini amat berkait dengan penggunaan teknologi dan aktiviti penyelidikan. Satu daripada implikasi penting model ini ialah saling bergantungan antara pemboleh ubah ekonomi yang membenarkan sesebuah industri mendapat manfaat daripada faktor luaran seperti pengetahuan. Dengan perkataan lain, ciri utama model pertumbuhan endogenos adalah wujudnya kesan limpahan melalui penyelidikan dan pembangunan (R\&D). Dari segi pengetahuan, kesan limpahan berlaku dalam bentuk pemindahan idea dan teknologi yang akhirnya menyumbang kepada pertumbuhan ekonomi. Kemajuan teknologi akan menyediakan insentif kepada pengumpulan modal, yang selanjutnya meningkatkan produktiviti buruh dan pertumbuhan ekonomi.

\section{KAJIAN LEPAS}

Secara keseluruhannya kebanyakan kajian lepas menemui bahawa sumbangan TFPG dalam sektor pembuatan di Malaysia masih kecil (lihat 
umpamanya Maisom dan Arshad 1992, Tham (1996); Nik Hashim 1998). Maisom dan Arshad (1992) dengan menggunakan data penyiasatan pembuatan di Malaysia antara tahun 1973-1989 pada tahap dua digit mendapati TFPG meningkat setiap tahun tetapi sumbangannya kepada pertumbuhan sektor pembuatan masih rendah. Dalam kajian ini juga mereka mendapati TFPG adalah lebih tinggi dalam industri yang banyak melibatkan pelaburan langsung asing dibandingkan dengan industri milik pelabur tempatan. Dalam kajian yang lain Maisom dan Mohd Ariff (1993) mengkaji TFPG bagi sektor pembuatan Malaysia pada 5 digit industri dan mendapati bahawa tahap TFPG adalah masih rendah berbanding dengan negara-negara lain yang sedang membangun. Keputusan kajian ini menunjukkan tahap produktiviti yang tinggi dicatat oleh industri yang berorientasikan pengguna, iaitu industri yang berintensifkan buruh. Selain daripada itu, industri dengan excess capacities mengalami pertumbuhan produktiviti yang rendah. Industri yang berorientasikan eksport termasuk pakaian, minyak sayuran dan lemak, kelapa sawit dan industri koko tergolong dalam kumpulan industri yang mempunyai TFPG yang tinggi. Sebaliknya industri penggantian import merupakan kumpulan industri yang mempunyai TFPG yang rendah.

Tham (1996) dengan menggunakan data penyiasatan pembuatan 1986-1991 dan kaedah Index-Translog Divisia dan data penyiasatan -pembuatan mendapati secara keseluruhannya TFPG dalam sektor pembuatan di Malaysia adalah rendah, iaitu pada 0.3\%. Bagi tahap subsektor pula, keputusan menunjukkan bahawa sembilan industri mengalami kadar perubahan teknikal tahunan purata di atas 1.0\% dengan subsektor pembuatan kaca dan produk kaca mencatatkan -nilai TFPG yang tertinggi, iaitu pada 7.1\% dan diikuti oleh subsektor produk galian bukan logam pada 5.0\%. TFPG yang rendah diperolehi dalam tempoh pertumbuhan yang tinggi dalam sektor pembuatan di Malaysia, iaitu pada 14.5\%. Menurut Tham (1996) faktor utama yang menyumbang kepada pertumbuhan positif TFP dalam sektor pembuatan ialah kadar pertukaran output, kadar pertukaran eksport dan pelaburan asing. Keputusan juga menunjukkan pertumbuhan produktiviti dalam sektor pembuatan di Malaysia mempunyai pengaruh yang positif dan signifikan oleh kadar pertumbuhan output, eksport dan pelaburan asing. Manakala faktor penentu yang memberi kesan yang negatif terhadap produktiviti dalam sektor pembuatan ialah nisbah modal-buruh, nisbah pelaburan kasar kepada stok modal dan kadar pertumbuhan import tahunan. 
Mahadevan (2002b; 2002c) menggunakan set data panel 28 buah industri dalam sektor pembuatan di Malaysia dari Penyiasatan Pembuatan tahun 1981 hingga 1996, TFPG diukur dan dibahagikan kepada perubahan teknikal (technical change) atau perubahan teknologi dan perubahan dalam kecekapan teknikal (technical efficiency) dengan menggunakan kaedah stochastic frontier. Kajian ini juga menunjukkan TFPG dalam sektor pembuatan di Malaysia adalah masih rendah. Dalam kajian yang lain Mahadevan (2002a) menggunakan data panel sektor pembuatan Malaysia yang sama, iaitu industri dari tahun 1981-1996 menganggarkan TFPG dengan menggunakan teknik Data Envelopment Analysis (DEA). Melalui kaedah ini kajian ini mendapati TFPG bagi sektor pembuatan Malaysia adalah rendah, iaitu pada $0.8 \%$ dan ia ditentukan oleh sumbangan yang kecil daripada perubahan teknikal dan kecekapan teknikal. TFPG yang paling tinggi ditunjukkan oleh industri keluaran logam bukan ferum, iaitu pada $3.7 \%$. Ianya diikuti oleh industri kulit binatang, iaitu sebanyak 3.0\% manakala industri kasut, tekstil, industri kimia dan industri kaca mencatatkan TFPG kurang daripada $0.5 \%$.

Nik Hashim dan Basri (2004) dengan menggunakan data penyiasatan pembuatan 1985-2000 dan kaedah stochstic frontier mendapati min kecekapan teknikal yang diperolehi ialah antara 0.735 (melalui model CD) dan 0.716 (melalui model TL). Pada tahun 2000, perubahan kecekapan teknikal dalam industri kimia adalah positif dan lebih tinggi berbanding industri lain dan ianya merupakan subsektor pembuatan yang paling aktif. Sementara industri atau subsektor yang paling tidak cekap ialah subsektor peralatan pengangkutan. Keputusan analisis TFPG pula menunjukkan kepelbagaiaan tahap pencapaian mengikut sub industri. Contohnya sumbangan buruh adalah positif dalam industri petroleum, kimia, kertas dan tekstil manakala sumbangannya adalah negatif dalam industri makanan dan elektrik dan elektronik. Industri kimia, getah, tekstil, kayu dan petroleum mempunyai kemajuan atau perubahan teknologi yang positif. Nilai perubahan teknologi yang paling tinggi dicatatkan oleh industri petroleum (3\% hingga 7\%). Walaupun TFPG dan kesan skel yang negatif telah dicatatkan oleh industri elektrik dan elektronik, namun begitu, industri tersebut mempunyai nilai kecekapan teknikal yang tinggi, iaitu sekitar 6\% hingga 15\%). Nilai kecekapan teknikal yang paling rendah telah dicatatkan dalam subsektor kelengkapan pengangkutan. 
Kajian Idris dan Rahmah (2005) menggunakan data Penyiasatan Pembuatan 1994-2000 bagi mengira TFPG sektor pembuatan di Malaysia melalui kaedah DEA. Hasil kajian ini mendapati TFPG pada keseluruhannya adalah negatif yang disebabkan oleh sumbangan kemajuan teknologi yang negatif. Walau bagaimanapun, kecekapan teknikal adalah positif dengan pertumbuhan indeks 1.107. Sub industri yang paling kurang cekap adalah industri keluaran galian bukan logam, diikuti oleh industri tekstil, pakaian dan kulit, serta industri kertas dan keluaran kertas. Dalam kebanyakan sub industri, kecekapan teknikal merupakan penyumbang yang lebih penting kepada TFPG dibandingkan dengan kemajuan teknologi. Contohnya bagi industri kertas dan keluaran kertas; kimia, petroleum dan arang batu; keluaran -getah dan plastik; galian bukan logam serta keluaran besi dan keluli. Sebaliknya industri ringan seperti makanan, minuman dan tembakau; kayu dan keluaran kayu serta tekstil, pakaian dan kulit sumber TFPG (1) lebih disumbangkan oleh perubahan teknologi.

Kebanyakan kajian lepas tentang TFPG di Malaysia memfokus kepada sub-industri dalam sektor pembuatan secara keseluruhannya tanpa membahagikannya mengikut saiz industri. Hanya kajian Rahmah dan Idris (1999; 2001), Nor Rizan (1999) dan Rahmah dan Nyet Fung (2002) mengkaji TFPG mengikut saiz industri dengan menggunakan pendekatan pertumbuhan perakaunan (growth accounting). Rahmah dan Idris (1999) menggunakan pendekatan pertumbuhan perakaunan untuk menganggar TFPG dalam industri pembuatan saiz besar di Malaysia dalam tempoh 1982-1994. Keputusannya menunjukkan bahawa industri saiz besar (ISB) mampu mencapai TFPG yang tinggi. Sumbangan TFPG dalam ISB adalah jauh lebih tinggi daripada sumbangan faktor lain dalam pertumbuhan output.

Kajian ini selanjutnya mendapati kadar pertumbuhan output adalah paling tinggi bagi industri minuman dan tembakau diikuti oleh peralatan pengangkutan dan galian bukan logam. Industri jenis lain yang mengalami kadar pertumbuhan yang tinggi, iaitu melebihi 10\% termasuklah industri kimia dan keluaran logam. Kadar pertumbuhan terendah dicapai dalam industri makanan diikuti oleh industri berasaskan getah, industri lain mengalami kadar pertumbuhan output antara 7\% hingga 8\%. Dalam kebanyakan industri sumbangan TFPG adalah lebih tinggi daripada sumbangan faktor lain kecuali bagi industri 
makanan dengan sumbangan TFPG hanya 39.6\% daripada jumlah kadar pertumbuhan output. Bagi industri minuman dan tembakau sumbangan TFPG adalah $64.0 \%$ diikuti oleh modal $25.7 \%$ dan buruh $10.2 \%$. Industri tekstil menikmati sumbangan TFPG yang agak tinggi juga pada $60.2 \%$ dan sumbangan modal $34.6 \%$. Sumbangan kuantiti buruh sangat rendah iaitu 5.2\%. Bagi industri berasaskan kayu dan berasaskan plastik TFPG menyumbang lebih 75\% dari sumbangan kuantiti buruh agak rendah. Sumbangan modal pula bagi kedua-dua industri ini adalah masingmasing $23.1 \%$ dan $16.1 \%$.

Industri berasaskan getah, kimia, keluaran logam, galian bukan logam dan peralatan pengangkutan menunjukkan keputusan sumbangan faktor buruh yang negatif terhadap output. Ini menggambarkan terlalu ramai buruh dan sebahagian memberi sumbangan negatif. Ini bermakna sekiranya sebahagian buruh dikurangkan kadar pertumbuhan output boleh meningkat. Sumbangan yang negatif ini diimbangi oleh sumbangan TFPG yang besar terutamanya bagi keluaran logam dan kimia dengan sumbangan melebihi 100\%. Ini menunjukkan industri logam dan kimia telah dapat menikmati kemajuan teknologi atau pembaikan input dengan pesat sekali. Sumbangan modal juga agak tinggi bagi sesetengah industri yang dikaji misalnya bagi industri berasaskan getah melebihi 50\%, peralatan elektrik $48.03 \%$ dan peralatan pengangkutan $37.7 \%$. Cuma bagi industri logam dan kimia sumbangan modal rendah iaitu masing-masing 1.1\% dan 3.3\% kerana kedua-dua sub-industri ini menikmati sumbangan TFPG yang sangat tinggi. Kajian Nor Rizan (1999) bagi data 1985-1994 pula mendapati, TFPG dalam IKS kimia dan minuman adalah negatif.

Sementara Rahmah dan Idris (2001) mengkaji TFPG secara menggabungkan ISK dengan ISS menjadi IKS dengan menggunakan data 1982-1994 dan mendapati TFPG lebih tinggi dalam industri yang lebih berintensifkan modal seperti industri logam fabrik dan peralatan pengangkutan, manakala TFPG adalah rendah dalam industri yang lebih berintensif buruh seperti makanan dan minuman. Dalam kajian ini mereka mendapati sumbangan modal melebihi 30\% daripada pertumbuhan $100 \%$ output dalam industri tekstil, pakaian dan kasut serta industri kimia. Dalam sub sektor IKS yang lain, sumbangan input modal secara positif adalah antara 1\% hingga 19.65\% dan yang terendah adalah dalam peralatan pengangkutan, walaupun industri 
ini lebih berintensifkan modal. Terdapat beberapa jenis industri yang menunjukkan sumbangan negatif input modal terhadap pertumbuhan output mereka. Ini termasuklah keluaran getah dan keluaran logam. Ini mungkin disebabkan oleh penggunaan modal yang sangat tinggi melebihi paras optimal kesan daripada kemasukan pelaburan langsung asing dalam industri-industri tersebut.

Hasil penelitian ini menunjukkan sub industri IKS yang mendapat manfaat yang tinggi daripada pertumbuhan input buruh adalah industri keluaran plastik dan peralatan pengangkutan dengan sumbangan melebihi 20\%. Terdapat beberapa industri yang menunjukkan sumbangan faktor buruh yang negatif terhadap pertubuhan output "mereka kesan daripada pertumbuhan negatif input tersebut sepanjang tempoh kajian, 1982-1994. Keadaan ini juga menggambarkan industriindustri ini mendapat manfaat yang besar daripada pengembangan (1) teknologi yang ditunjukkan oleh sumbangan faktor baki atau TFPG. Enam kumpulan IKS yang mendapat manfaat yang tinggi daripada TFPG termasuklah makanan, minuman dan tembakau, berasaskan kayu, keluaran getah, keluaran logam, keluaran galian bukan logam dan peralatan elektrik. Nilai TFPG bagi keenam-enam industri ini melebihi kadar pertumbuhan output mereka.

Sementara kajian Rahmah dan Nyet Fung (2002) menggunakan data Penyiasatan Pembuatan 1981-1994 dan kaedah stochastic frontier mengkaji sumbangan TFPG dalam enam sub sektor pembuatan. Mereka mendapati bahawa perubahan kecekapan teknikal menurun dari tahun 1981 ke tahun 1994 dalam industri bersaiz kecil tetapi meningkat dalam industri bersaiz sederhana. Walau bagaimanapun sumbangan kemajuan teknologi kepada TFPG meningkat dalam kedua-dua saiz industri. TFPG adalah lebih tinggi dalam industri bersaiz sederhana tetapi sumbangan TFPG kepada pertumbuhan output adalah lebih tinggi dalam industri bersaiz kecil. Kajian ini mendapati sumbangan TFPG kepada pertumbuhan ouput Industri Skel Kecil (ISK) adalah lebih tinggi daripada sumbangannya dalam Industri Skel Sederhana (ISS). Sumbangan yang tinggi didapati dalam industri berasaskan getah dan berasaskan kayu serta industri makanan. Dalam sesetengah industri ISS dan ISK yang dikaji terdapat juga sumbangan negatif TFPG terhadap pertumbuhan output, contohnya yang berlaku dalam industri ISS minuman dan ISK keluaran kimia. 
Kebanyakan kajian berkaitan impak teknologi terhadap pertumbuhan output menggunakan pelbagai pendekatan dalam mengukur perubahan teknologi seperti trend masa (lihat Solow 1956), penyelidikan dan pembangunan (R\&D) yang berlaku dalam organisasi pengeluaran serta pengetahuan pekerja (lihat umpamanya Goo \& Park 2007; Pintea \& Thompson 2007) atau jenis mesin yang digunakan dalam sesebuah loji pengeluaran (lihat Branstetter \& Chen 2006). Pengukuran pembangunan teknologi pula selalunya dilihat melalui proses yang boleh menyumbang ke arah teknologi baru seperti $R \& D$, infrastruktur asas, teknologi maklumat, kesediaan tenaga, pengurusan teknologi, persekitaran teknologi, reka bentuk dan hak cipta, telekomunikasi, perkhidmatan internet, projek pengangkutan dan e-perdagangan (lihat umpamanya Sieh et al. 2004; Wang \& Chien 2007) .

Kajian Branstetter dan Chen (2006) bagi loji industri di Taiwan mendapati terdapat hubungan yang positif dan signifikan antara teknologi diimport dan R\&D terhadap pertumbuhan output dan produktiviti industri. Namun kajian Braga dan Willmore (1991) di Brazil mendapati walaupun kesan teknologi diimport terhadap pertumbuhan output adalah positif, kesan jangka panjangnya tidak dapat di analisis kerana menggunakan data keratan rentas. Pintea dan Thompson (2007) mengaitkan teknologi dengan R\&D dan pencapaian pendidikan. Namun hasil kajian beliau tidak menunjukkan hubungan yang positif antara R\&D dan pendidikan dengan produktiviti buruh akibat kurangnya penyesuaian teknologi baru.

Kajian ini mengukur teknologi hasil daripada pengiraan indeks Malmquist melalui pendekatan DEA. Dalam pendekatan ini kesan perubahan teknologi dikira melalui dua input dan satu output dan proses ini mampu menghasilkan perubahan kecekapan teknikal dan perubahan teknologi. Tidak ada kajian sebelum ini yang menggunakan pendekatan ini dalam melihat kesan perubahan teknologi terhadap pertumbuhan output industri. Pengukuran ini dianggap boleh menyelesaikan kesukaran mengukur perubahan teknologi seperti yang dihadapi oleh penyelidik sebelumnya.

\section{SPESIFIKASI MODEL DAN DATA}

Bahagian ini menumpukan kepada model pertumbuhan output bagi melihat kesan perubahan teknologi terhadap pertumbuhan output 
IKS. Model yang digunakan adalah berasaskan kepada kepada fungsi pengeluaran Cobb -Douglas. Dalam model ini pemboleh ubah bersandar adalah pertumbuhan output IKS dan pemboleh ubah bebas terdiri daripada pertumbuhan input modal dan buruh serta perubahan teknologi yang diperolehi dari prosedur DEA. Model regresi boleh ditulis seperti berikut:

$$
\ln Y_{i t}=\beta_{0}+\beta_{1} \ln K_{i t}+\beta_{2} \ln L_{i t}+\beta_{3} P T_{i t}+\mu_{i t}
$$

dengan,

1n $Y_{i t}$ adalah natural logarithm bagi output IKS sektor i pada tahun $\mathrm{t}$

-1n $K_{i t}$ adalah natural logarithm bagi nilai aset tetap IKS sektor i pada tahun $\mathrm{t}$

1n $L_{i t}$ adalah natural logarithm bagi kuantiti buruh IKS sektor i pada tahun $\mathrm{t}$

-

PT adalah perubahan teknologi

$\mu_{i t}$ adalah pemboleh ubah ralat

Sumber data untuk tujuan analisis adalah Penyiasatan Industri Pembuatan tahun 1985-2003 dari Jabatan Perangkaaan Malaysia. Tahap industri yang dipilih adalah pada MSIC 3 digit yang merangkumi 10 sub IKS.

\section{ANALISIS KEPUTUSAN PENGANGGARAN}

\section{Punca Pertumbuhan Produktiviti Faktor Keseluruhan}

Jadual 3 menunjukkan keputusan kajian daripada prosedur DEA. Hasil kajian menunjukkan antara tahun 1985-2003 TFPG dalam IKS di Malaysia adalah negatif disebabkan oleh pertumbuhan negatif keduadua kecekapan teknikal dan teknologi. Namun, analisis mengikut sub industri menunjukkan terdapat sesetengah industri mengalami TFPG positif dan beroperasi pada output potensi yang maksimum. Terdapat tiga jenis industri, iaitu makanan dan minuman, tekstil dan keluaran plastik mencapai TFPG positif. Ini bermakna hanya tiga jenis IKS ini yang berjaya mencapai output perbatasan melalui inovasi dan kecekapan. IKS 
tekstil mencatatkan TFPG tertinggi pada 10.4\% setahun, diikuti oleh IKS makanan dan minuman pada $7.6 \%$ dan IKS keluaran plastik pada $4.1 \%$. Ketiga-tiga jenis industri adalah merupakan industri ringan yang lebih berintensifkan buruh serta beroperasi pada tahap teknologi yang agak rendah.

Jadual 3

Purata Perubahan Kecekapan Teknikal, Perubahan Teknologi dan Produktiviti Faktor Keseluruhan, 1985 - 2003

\begin{tabular}{lccc}
\hline \multicolumn{1}{c}{ Industri } & $\begin{array}{c}\text { Perubahan } \\
\text { kecekapan } \\
\text { teknikal }\end{array}$ & $\begin{array}{c}\text { Perubahan } \\
\text { teknologi }\end{array}$ & $\begin{array}{c}\text { Perubahan } \\
\text { produktiviti } \\
\text { faktor } \\
\text { keseluruhan }\end{array}$ \\
\hline Makanan dan Minuman (311-313/151-155) & 1.062 & 1.014 & 1.076 \\
Tekstil (321-324/171-192) & 1.119 & 0.987 & 1.104 \\
Berasakan Kayu 331-332/201-202,361) & 1.028 & 0.965 & 0.993 \\
Keluaran Plastik (356/252) & 1.076 & 0.968 & 1.041 \\
Berasaskan Getah (355/251) & 0.839 & 1.035 & 0.869 \\
Keluaran Kimia (351-352/241-243) & 0.796 & 1.017 & 0.810 \\
Keluaran Logam (369/272) & 0.862 & 1.012 & 0.872 \\
Keluaran galian bukan logam (369/269) & 0.775 & 0.943 & 0.731 \\
Elektrik dan Elektronik (382-383/291-323) & 0.844 & 0.952 & 0.804 \\
Peralatan Pengangkutan (384/341-359) & 0.726 & 0.956 & 0.694 \\
Keseluruhan & 0.916 & 0.987 & 0.904 \\
\hline
\end{tabular}

Nota. angka dalam kurungan adalah kod industri yang diselaraskan bagi tempoh 1981-1999 dan 2000-2003.

TFPG dalam industri makanan dan minuman, tekstil, kayu dan plastik adalah disumbangkan oleh perubahan kecekapan teknikal dengan purata pertumbuhan antara 1.028 to 1.119 . Keupayan mencapai perubahan kecekapan teknikal yang tinggi adalah hasil daripada peningkatan modal manusia atau pengurusan input yang lebih baik. IKS yang paling tidak efisien ialah peralatan pengangkutan yang menunjukkan output masih boleh ditingkatkan sebanyak $27.4 \%$ tanpa meningkatkan penggunaan input.

\section{Keputusan Penganggaran Model Pertumbuhan IKS}

Jadual 4 menujukkan hasil penganggaran persamaan (2). Setelah menjalankan ujian serial correlation didapati beberapa industri seperti tekstil, keluaran getah, dan kimia mengalami masalah ini dan ianya 
diperbetulkan melalui kaedah iterative Cochrane. Hasil daripada analisis ini menunjukkan nilai $\mathrm{R}^{2}$ bagi semua IKS adalah melebihi 0.7 yang menunjukkan lebih $70 \%$ variasi dalam pemboleh ubah bersandar dapat diterangkan oleh pemboleh ubah bebas.

\section{Jadual 4}

Keputusan penganggaran persamaan regresi pertumbuhan output IKS 19852003

\begin{tabular}{|c|c|c|c|c|c|c|}
\hline Industri & Pemalar & Modal & Buruh & $\begin{array}{c}\text { Perubahan } \\
\text { Teknologi }\end{array}$ & $\mathrm{R}^{2}$ & LM test ${ }^{1}$ \\
\hline \multirow{2}{*}{$\begin{array}{l}\text { Makanan dan } \\
\text { Minuman }\end{array}$} & 2.2601 & $0.3202^{* *}$ & $0.5828^{*}$ & $0.1421^{*}$ & \multirow[b]{2}{*}{0.75778} & \\
\hline & (2.694) & $(2.332)$ & $(2.010)$ & $(1.744)$ & & \\
\hline \multirow[t]{2}{*}{ Tekstil } & 0.7975 & $1.0103^{* *}$ & 0.1953 & $0.2029^{* *}$ & \multirow{2}{*}{0.7384} & 5.6239 \\
\hline & $(0.766)$ & $(2.162)$ & $(0.814)$ & $(2.252)$ & & $(0.01771)$ \\
\hline \multirow{2}{*}{ Berasaskan Kayu } & 1.8327 & $1.7920^{* * *}$ & $0.8742^{* * *}$ & $0.3270^{*}$ & \multirow{2}{*}{0.7167} & \\
\hline & $(2.349)$ & $(3.891)$ & $(4.039)$ & (2.033) & & \\
\hline \multirow[t]{2}{*}{ Keluaran Plastik } & 1.8541 & 0.1852 & $0.8983^{*}$ & $0.1841^{* *}$ & \multirow{2}{*}{0.8834} & \\
\hline & (1.873) & $(0.233)$ & $(2.025)$ & $(2.593)$ & & \\
\hline \multirow[t]{2}{*}{ Berasaskan Getah } & 4.1578 & 0.0387 & 0.0650 & 0.0815 & \multirow{2}{*}{0.2073} & 5.9518 \\
\hline & $(4.747)$ & $(0.195)$ & $(0.938)$ & $(1.091)$ & & $0.01470)$ \\
\hline \multirow[t]{2}{*}{ Kimia } & -0.1045 & $0.8151^{* *}$ & $0.5325^{* *}$ & 0.0245 & \multirow{2}{*}{0.7683} & 10.6049 \\
\hline & $(-0.114)$ & $(2.519)$ & $(2.842)$ & $(0.393)$ & & $(0.00113)$ \\
\hline \multirow[t]{2}{*}{ Keluaran Logam } & 1.1329 & 0.1666 & $0.7577^{* * *}$ & 0.0244 & \multirow{2}{*}{0.8009} & \\
\hline & $(1.801)$ & $(0.430)$ & (3.306) & $(0.341)$ & & \\
\hline \multirow{2}{*}{$\begin{array}{l}\text { Keluaran Galian Bukan } \\
\text { Logam }\end{array}$} & 0.8569 & $0.8127^{* *}$ & $0.3094^{*}$ & 0.0369 & \multirow{2}{*}{0.7758} & \\
\hline & $(0.912)$ & $(2.186)$ & $(1.686)$ & $(1.6468)$ & & \\
\hline \multirow[t]{2}{*}{ Elektrik dan Elektronik } & 2.9883 & $0.8580^{*}$ & $1.2005^{* * *}$ & $0.1373^{*}$ & \multirow{2}{*}{0.8221} & \\
\hline & $(1.975)$ & $(1.855)$ & $(6.846)$ & $(1.844)$ & & \\
\hline \multirow[t]{2}{*}{ Peralatan Pengankutan } & 3.0117 & 1.2668 & $1.4082^{* * *}$ & $0.0960^{*}$ & \multirow{2}{*}{0.7893} & \\
\hline & $(3.530)$ & $(1.730)$ & (3.149) & $(1.796)$ & & \\
\hline
\end{tabular}

Nota. ${ }^{1}$ Breusch-Godfrey Serial Correlation LM Test: $(\mathrm{n}-1) \mathrm{R}^{2}$

Angka dalam kurungan di bawah nilai ujian LM adalah Chi-square(1).

Angka dalam kurungan adalah nilai statistik t.

*** - signifikan pada aras keertian1 peratus.

** - signifikan pada aras keertian 5 peratus.

* -signifikan pada aras keertian 10 peratus.

Dalam enam sub IKS, iaitu makanan dan minuman, tekstil, keluaran kayu, keluaran plastik, elektrik dan elektronik dan peralatan pengangkutan keputusan kajian menunjukkan perubahan teknologi memainkan peranan yang signifikan dalam menentukan pertumbuhan output mereka. Pertumbuhan input buruh adalah signifikan dalam 
menentukan pertumbuhan lapan sub IKS kecuali tekstil dan keluaran berasaskan getah. Pertumbuhan input modal pula merupakan penentu pertumbuhan output IKS yang signifikan dalam enam sub industri kecuali bagi keluaran plastik, berasaskan getah, keluaran logam dan peralatan pengangkutan.

Apabila menganalisis mengikut setiap sub industri dalam IKS yang dikaji, didapati bagi IKS berasaskan getah tiada satu pun pemboleh ubah yang signifikan. Sementara kedua-dua pertumbuhan input menerangkan dengan signifikan pertumbuhan output bagi IKS makanan dan minuman, berasaskan kayu, kimia, keluaran galian bukan logam dan elektrik dan elektronik. Dalam industri berasaskan kayu, peningkatan $1 \%$ dalam input buruh meningkatkan pertumbuhan output sebanyak $0.87 \%$, manakala peningkatan $1 \%$ dalam pertumbuhan input modal akan meningkatkan pertumbuhan output sebanyak $1.79 \%$. Bagi IKS kimia, peningkatan $1 \%$ dalam input modal meningkatkan pertumbuhan output sebanyak $0.81 \%$, manakala peningkatan $1 \%$ dalam input buruh meningkatkan pertumbuhan output industri ini sebanyak $0.53 \%$. Dalam IKS keluaran galian bukan logam pula, peningkatan 1\% dalam pertumbuhan input buruh akan meningkatkan pertumbuhan output sebanyak $0.31 \%$, manakala peningkatan $1 \%$ dalam pertumbuhan input modal akan meningkatkan pertumbuhan output sebanyak $0.81 \%$. Bagi IKS kimia, galian bukan logam dan keluaran kayu kesan pertumbuhan modal terhadap pertumbuhan output adalah lebih tinggi daripada kesan pertumbuhan input buruh. Sebaliknya, kesan buruh adalah lebih tinggi dalam dua sub IKS, iaitu makanan dan minuman serta elektrik dan elektronik.

\section{RUMUSAN DAN KESIMPULAN}

Perbincangan menunjukkan secara keseluruhannya TFPG dalam IKS di Malaysia adalah negatif kesan daripada pertumbuhan negatif kecekapan teknikal dan perubahan teknologi. Walau bagaimanapun, apabila melihat setiap jenis sub industri terdapat beberapa sub IKS yang mengalami TFPG positif antara 1985-2003 seperti dalam industri ringan dan lebih berintensifkan buruh seperti makanan dan minuman, pakaian dan keluaran plastik. TFPG yang positif dalam ketiga-tiga sub IKS ini adalah disumbangkan oleh perubahan kecekapan teknikal yang positif. IKS yang lebih berintesifkan modal dan berteknologi lebih tinggi seperti peralatan pengangkutan dan kimia didapati kurang cekap dan dalam masa yang sama tidak mampu menikmati TFPG yang positif. Selanjutnya 
kajian ini mendapati perubahan teknologi adalah merupakan penentu pertumbuhan output IKS yang signifikan dalam enam sub industri, iaitu makanan dan minuman, tekstil, keluaran berasaskan kayu, keluaran plastik, elektrik dan elektronik dan peralatan pengangkutan. Dalam sub IKS lain, perhubungan antara perubahan teknologi dan pertumbuhan output juga positif walaupun tidak signifikan.

Hasil kajian ini membawa kepada beberapa implikasi dasar berkaitan dengan pembangunan IKS di Malaysia. Pencapaian TFPG negatif dalam IKS seperti yang ditunjukkan dalam kajian ini dapat dikaitkan dengan dua aspek, iaitu ketakcekapan dan perubahan teknologi yang perlahan. Bagi meningkatkan kecekapan, saiz operasi IKS perlu diperbesarkan. Pembesaran saiz operasi membolehkan IKS menikmati ekonomi ikut -bidang. Selanjutnya kos pengeluaran purata dapat diturunkan dan harga output direndahkan. Ini akan meningkatkan produktiviti pekerja, kecekapan, keuntungan serta daya siang industri.

CPerubahan teknologi menyumbang secara positif kepada pertumbuhan output kebanyakan IKS, walaupun perubahan teknologi yang berlaku adalah negatif. Ini menggambarkan peningkatan dalam penggunaan teknologi adalah penting dan sejajar dengan hasrat kerajaan supaya operasi pengeluaran di Malaysia bergerak ke arah penggunaan teknologi tinggi. Perubahan atau kemajuan teknologi boleh berlaku sama ada melalui penyelidikan dan pembangunan (R\&D) atau sering dirujuk sebagai pembangunan teknologi dan pemindahan teknologi. Oleh itu, IKS perlu meningkatkan aktiviti R\&D untuk mencipta inovasi dalam teknik pengeluaran dan produk baru serta menerokai pasaran yang lebih luas. Pemindahan teknologi diperoleh melalui pelaburan langsung asing atau pembelian input asing. Walaupun kesan pemindahan "teknologi ini boleh membawa kepada peningkatan output, namun ia boleh meninggalkan kesan negatif dari aspek lain seperti kekurangan daya penyerapan kemahiran tempatan.

Kualiti input seperti buruh dan modal amat penting dalam meningkatkan kecekapan industri. Oleh itu, IKS perlu meningkatkan kualiti modal, contohnya melalui penggunaan teknologi yang sesuai yang dijana melalui R\&D. Kualiti buruh pula boleh ditingkatkan melalui pembangunan sumber manusia seperti pendidikan dan latihan semasa kerja. IKS perlu menekankan aspek latihan pekerja dengan membiayai mereka untuk menghadiri latihan tertentu. Pihak industri juga sepatutnya menyediakan kemudahan latihan di tempat kerja yang boleh menawarkan program latihan seperti yang diperlukan. 
Penemuan kajian inijuga menunjukkan industri yang lebih berintensifkan modal dan berteknologi lebih tinggi adalah kurang cekap dan mencapai TFPG yang lebih rendah. Ini menggambarkan ketidakfisienan dalam penggunaan modal yang ada kaitannya dengan penggunaan teknologi yang kurang sesuai. Kemungkinan juga berlaku ketaksepadanan antara teknologi yang digunakan dengan kemahiran buruh yang dimiliki. Oleh itu, IKS ini perlu merancang komposisi buruh yang sesuai dengan tahap teknologi yang digunakan. Dalam hal ini, perancangan produk dan tenaga kerja amat penting dilakukan.

Sebagai kesimpulannya, IKS sememangnya merupakan tunjang pertumbuhan perindustrian di Malaysia dan kecekapannya amat perlu dipertingkatkan. IKS perlu merebut peluang dan kemudahan yang telah disediakan kerajaan. Sehingga ke hari ini, memang banyak bantuan dan program kerajaan untuk IKS yang merangkumi pelbagai aspek seperti kewangan, teknikal, pembangunan sumber manusia dan pemasaran. Terpulanglah kepada IKS sendiri untuk memanfaatkan kemudahan ini.

\section{RUJUKAN}

Broga, H., \& 1. Willmore (1991). Technological imports and technological effort: An analysis of their determinants in Brazilian Firms. Journal of Industrial Economics, 39, 421-432.

Denison, Edward F. (1974). Accounting for U.S. Growth 1929-1969. Washington: The Brookings Institution.

Idris Jajri, \& Rahmah Ismail. (2005). Total Factor Productivity Growth in Malaysian Manufacturing Sector. Kertas kerja dibentangkan dalam $9^{\mathrm{TH}}$ PRSCO Conference, Tokyo, Japan, July 2005.

Jabatan Perangkaan Malaysia. (2006). Maklumat Penyiasatan Industri Pembuatan, 2003. Kuala Lumpur.

Jabatan Perangkaan Malaysia. Laporan Penyiasatan Industri Pembuatan, Pelbagai Tahun.

Kementerian Perdagangan Antarabangsa dan Industri Malaysia (MITI). (1996). Pelan Induk Perindustrian Kedua, 1996-2005, Ringkasan Eksekutif, Kuala Lumpur.

Lee Branstetter \& Jong-Rong Chen (2006). The impact of technology transfer and R\&D on productivity growth in Taiwanese industry. The Journal of the Japanese and International Economics, 20, 177-192.

Lucas, R.E. Jr. (1988). On the mechanics of economic development. Journal of Monetary Economics, 22, 3-42. 
Malaysia. (2001). Rancangan Malaysia Kelapan, 2001-2005. Kuala Lumpur: Percetakan Kerajaan Malaysia.

Malaysia. (2006). Rancangan Malaysia ke Sembilan, 2006-2010. Kuala Lumpur: Percetakan Kerajaan Malaysia.

Mahadevan, R. (2002c). Is there the real TFP growth measure for the Malaysia's Manufacturing Sector. ASEAN Economic Bulletin, 19(2), 178-190.

Mahadevan, R. (2002b). A DEA approach to understanding the productivity growth of Malaysia's manufacturing industries. Asia Pacific Journal of Management, 19(4), 587-600.

Mahadevan, R. (2002a). Is output growth of Korean manufacturing firms productivity driven? Paper presented at the $8^{\text {th }}$ Convention of the East Asian Economic Association, 4-5 November, 2002, Kuala Lumpur.

Maisom, Abdullah, \& Arshard Marshidi. (1992). Pattern of total productivity growth in Malaysia manufacturing industries, 1973-1989. Serdang: Universiti Pertanian Malaysia.

(D) Maisom, Abdullah, \& Mohd Ariff. (1993). Total factor productivity growth in Malaysian resource based industries. Asian Economic Bulletin, 10(1).

Mihaela lulia Pintea \& Peter Thompson, (2007). Technological complexity and economic growth. Review of Economics Dynamics, 10 (2) 276293.

Nik Hashim, Nik Mustapha. (1998). Output versus productivity growth in the manufacturing industry. An experience for sustainable development planning, Bengkel Fakulti Ekonomi, 19-21 Jun, Port Dickson.

Nik Hashim, Nik Mustapha, \& Basri Abdul Talib. (2004). Technical efficiency and total factor productivity growth for manufacturing industries. Fakulti Ekonomi dan Perniagaan, 2004.

Nor Rizan, Mohd. Thani. (1999). Pembangunan industri kecil dan sederhana di Malaysia: Analisis prestasi produktiviti. Kertas Ilmiah Sarjana, Fakulti Ekonomi, UKM.

Rahmah, Ismail, \& Idris Jajri. (1999). Sources of productivity growth in large scale industries in Malaysia. Journal Ekonomi Malaysia 34, 5957.

Rahmah, Ismail, \& Idris Jajri. (2001). Comparing total factor productivity in small and medium scale enterprises. In SMEs at the Crossroad, ed. Moha Asri Abdullah. United Kingdom: Wisdom House Publication.

Rahmah, Ismail, \& Chai Nyet Fung. (2002). Sumbangan produktiviti keseluruhan terhadap output industri skel kecil dan sederhana: Satu analisis perbatasan stokastik. Jurnal Analisis, 9, 77-99. 
Rahmah, Ismail. (2007). Pembangunan sumber manusia dalam industri skala kecil dan sederhana. Bangi: Penerbit Universiti Kebangsaan Malaysia.

Romer, P. (1989). Capital accumulation and long-run growth, in R.J. Barro ed. Modern business cycle theory, MA Cambridge, MA: Harvard University Press.

Schultz, T.W. (1961). Investment in human capital. American Economic Review, 51(1), 1-17.

Solow, R.M. (1956). A contribution to theory of economic growth. Quarterly Journal of economics, 70, 65-94.

Solow, R.M. (1957). Technical change and the agregate productions function. The Review of Economic Statistics, Vol. XXXIX. August: 312-319.

Tham Siew Yean. (2000). Ukuran dan penentuan produktiviti faktor keseluruhan sektor pembuatan di Malaysia. Dalam Ekonomi Malaysia Menghadapi dan Menangani Cabaran disunting oleh Md. Zhahir Kechot, Mansor Jusoh. Penerbitan UKM. Bangi 2000. 